\title{
Genetic parameter and genetic trend estimates for reproductive traits in Wistar rats
}

[Estimativas de parâmetros genéticos e tendências genéticas de características reprodutivas em ratos Wistar]

\author{
G. Taroco ${ }^{1}$, J.T. Paiva ${ }^{2 *}$, G.B. Mourão ${ }^{3}$, J.B.S. Ferraz ${ }^{4}$, E.C. Mattos $^{4}$, \\ J.P. Eler ${ }^{4}$, D.R. Resende ${ }^{5}$, L.G. Gaya ${ }^{5}$
}

${ }^{1}$ Universidade Federal de Lavras - Lavras, MG

${ }^{2}$ Universidade Federal de Viçosa - Viçosa, MG

${ }^{3}$ Universidade de São Paulo - Piracicaba, SP

${ }^{4}$ Universidade de São Paulo - Pirassununga, SP

${ }^{5}$ Universidade Federal de São João del Rei - São João del Rei, MG

\begin{abstract}
The aim of this study was to estimate genetic parameters and genetic trends for reproductive traits in Wistar rats. A total of 1,167 data records from 283 females over six generations of monogamous mating pairs was used. Heritability and genetic correlation were estimated through Bayesian inference and genetic trends were calculated by linear regression of breeding values over generations. Heritability estimates for litter size at birth (LS), calving interval (CI), pup mortality (PM) and maternal cannibalism (CAN) presented low magnitude, ranging from 0.01 to 0.13 . CAN presented high and positive genetic correlation with LS and PM (0.77 and 0.78, respectively). On the other hand, all the other estimated genetic correlations were not significant. Genetic trend was positive for LS (+0.0900 pups per generation), and negative for PM and CAN $(-1.0085$ and -0.5217 pups per generation, respectively). For CI the genetic trend was not significant. It is recommended to increase selection intensity on dams in this Wistar rat population in order to accelerate the genetic progress.
\end{abstract}

Keywords: genetic correlation, heritability, selection criteria, Wistar

\section{RESUMO}

O objetivo deste estudo foi estimar os parâmetros genéticos e as tendências genéticas de características reprodutivas em ratos Wistar. Foram analisados 1.167 registros coletados em 283 fêmeas ao longo de seis gerações de pares de acasalamentos monogâmicos. Herdabilidade e correlação genética foram estimadas por meio de inferência bayesiana, e as tendências genéticas foram calculadas pela regressão linear dos valores genéticos em função das gerações. As estimativas de herdabilidades para as características número de filhotes nascidos (LS), intervalo de parto (CI), mortalidade de filhotes (PM) e canibalismo materno (CAN) foram de baixa magnitude $(0,01$ a 0,13$)$. CAN apresentou correlação genética alta e positiva com LS e PM, 0,77 e 0,78, respectivamente. As demais correlações genéticas estimadas foram não significativas. A tendência genética foi positiva para $L S(+0,0900$ filhote por geração) e negativa para PM e CAN (-1,0085 e-0,5217 filhote por geração, respectivamente). A tendência genética não foi significativa para CI. Recomenda-se aumentar a intensidade de seleção nas fêmeas nessa população de ratos Wistar, a,fim de acelerar o progresso genético.

Palavras-chave: correlação genética, herdabilidade, critério de seleção, Wistar

Recebido em 21 de agosto de 2019

Aceito em 10 de dezembro de 2019

*Autor de correspondência (corresponding author)

E-mail: teo.paiva@hotmail.com 


\section{INTRODUCTION}

Mice and rat have always been one of the most applied animal models, widely used in selection experiments over short generation intervals (Formoso-Rafferty et al., 2016; Arends et al., 2018). The Wistar lineage rats (Rattus novergicus) has been prominently used in this regard. The demand for these rodents has increased in recent decades which requires greater control regarding the management conditions and housing environment (Mattaraia and Moura, 2012; Arends et al., 2018). In this context, it is important to evaluate the reproductive traits since they have a great impact on profitability in animal production systems. Breeding room sanitation management and improvements are also required. Besides, the inclusion of reproductive traits in selection programs can bring genetic gains with higher productive performance of dams. Genetic improvement of prolificacy traits in mice has considerable importance for total productivity (Fernández et al., 1998).

Among most breeding goals, the litter size is an important trait to be considered on the rat production system (Peripato et al., 2004). Usually, the breeding goal is to increase the number of weaned pups per female (Fernández et $a l ., 1998)$. Variation in litter size along with the calving interval, pup mortality and maternal cannibalism can be selection main targets. Korpela et al. (2010) observed that the high population density affects male aggressive behavior and suggests selective infanticide of females in order to reduce future competition in rats (Myodes glareolus). Mattaraia and Moura (2012) reported that the mating system (monogamous and polygamous) adopted in the reproductive management of Wistar rats can influence the pup mortality and calving intervals. Moreover, Tarôco et al. (2015) reported that genetic and environmental factors are related to dam's behavior and may influence maternal cannibalism by reducing the number of weaned animals in Wistar rats.

Evaluations concerning genetic factor influences on reproductive traits can help to bring genetic gains in production indices. Estimated genetic parameters for reproductive traits are primordial to guide the selection process in animal breeding programs. In addition, the estimation of (co)variance component is essential to predict accurate breeding values (Lukač et al., 2016). Therefore, through knowledge of the genetic architecture of economically important traits, it is possible to define the best dam selection strategy in order to increase Wistar rat production. Besides, evaluating the genetic trend of each trait over time is an important mechanism for monitoring the selection process and its efficiency in breeding programs (Rout et al., 2017).

To the best of our knowledge, there are few reports about the genetic parameters for the analyzed traits in Wistar rats. Thus, the aim of the study was to estimate genetic parameters and genetic trends for litter size at birth, calving interval, pup mortality and maternal cannibalism in a Wistar rat population under conventional breeding conditions. The obtained results may be useful to exploit the heritability and genetic correlations for breeding program purposes in this population.

\section{MATERIAL AND METHODS}

Reproductive traits records of 283 female Wistar rats (Rattus novergicus) under a conventional breeding system at the Central Vivarium of the Federal University of São João del-Rei were used. The data were collected from August 2010 to January 2012. The study was approved by the Ethics Committee on the Use of Animal at the Federal University of São João del-Rei, São João del-Rei, Minas Gerais, Brazil (Protocols n. 009/2010 and 023/2010).

The animals were distributed to create monogamous mating pairs in an exclusive room for breeders and each pair was kept in individual cages. These cages had dimensions of $49 \times 34 \times 16 \mathrm{~cm}$, and they were equipped with a clean wood shaving bed replaced every two days. The rats were maintained in an environment at a controlled temperature (between 18 and $22^{\circ} \mathrm{C}$ ) and a 12-h light cycle. Feed and water were provided ad libitum. Data records were collected daily from pup birth to weaning. The population was empirically submitted to a phenotypic selection, aiming at a higher litter size at birth.

Evaluated maternal reproductive traits were litter size at birth (LS), calving interval (CI), pup mortality (PM), and maternal cannibalism (CAN). LS was measured as the number of born pups (alive and stillbirth) per female in each parturition. 
CI was calculated as the difference (in days) between the previous and subsequent calving of each dam. PM was calculated by the proportion of pups found dead in the cages (natural deaths), from birth to weaning within a litter. CAN was calculated by the proportion of missing or mutilated pups found in the cages from birth to weaning within a litter.

Descriptive statistics were calculated using the Statistical Analysis System ${ }^{\circledR}$ software (Statistical..., 2008). The systematic effects and covariates associated to each trait were evaluated using the same software, assuming a level of $5 \%$ statistical significance. For CI, the contemporary groups were formed by the order and parity week effects and as a covariate was included the parity age of dam (in days). For PM and CAN, the contemporary groups were formed by room density effect defined as the number of animals in the room on the parity day (class 1 - from 50 to 100 animals, class 2 - from 101 to 150 animals, and class 3 - from 151 to 169 animals) and parity week effect. For LS, the contemporary groups were formed by the dam parity order effect. Individual records whose contemporary groups contained less than five animals were eliminated. The numerator relationship matrix comprised 1,242 animals.

The following bivariate Bayesian model was fitted: $\mathrm{y}=\mathrm{Xb}+\mathrm{Za}+\mathrm{Zp}+\mathrm{e}$, where $\mathrm{y}$ is the vector of phenotypic observations, $b$ is the vector of systematic effects (contemporary groups and covariates), a is the vector of random additive genetic effects, $p$ is the vector of random permanent environmental effects, $\mathrm{X}$ and $\mathrm{Z}$ are the incidence matrices of systematic and random effects, respectively, and e is the vector of random residual effects. The adopted model had the following distributions: $\mathrm{y} \mid \mathrm{b}, \mathrm{a}, \mathrm{p}, \mathrm{e} \sim \mathrm{N}(\mathrm{Xb}+\mathrm{Za}+$ $\left.\mathrm{Zp}, \mathrm{R}_{0} \otimes \mathrm{I}\right) ; \mathrm{b} \sim \mathrm{N}\left(0, \Sigma_{\mathrm{b}}\right)$, in which $\Sigma_{\mathrm{b}}$ is a diagonal matrix with values to represent vague prior knowledge; $\mathrm{a}\left|\mathrm{G}_{0} \sim \mathrm{N}\left(0, \mathrm{G}_{0} \otimes \mathrm{A}\right) ; \mathrm{p}\right| \mathrm{P}_{0} \sim \mathrm{N}\left(0, \mathrm{P}_{0}\right.$ $\otimes \mathrm{I})$; and e $\mid \mathrm{R}_{0} \sim \mathrm{N}\left(0, \mathrm{R}_{0} \otimes \mathrm{I}\right)$, where $\mathrm{G}_{0}, \mathrm{P}_{0}$, and $\mathrm{R}_{0}$ are the additive genetic, permanent environmental, and residual (co)variances matrices, respectively; $\mathrm{A}$ is the numerator relationship matrix among the animals; and I is the identity matrix. Furthermore, it was assumed that the (co)variance matrices follow an inverted Wishart distribution: $\mathrm{G}_{0} \mid \mathrm{v}_{\mathrm{a}}, \mathrm{V}_{\mathrm{a}} \sim \mathrm{W}^{-1}\left(\mathrm{v}_{\mathrm{a}}, \mathrm{V}_{\mathrm{a}}\right) ; \mathrm{P}_{0}$ $\mid \mathrm{v}_{\mathrm{p}}, \mathrm{V}_{\mathrm{p}} \sim \mathrm{W}^{-1}\left(\mathrm{v}_{\mathrm{p}}, \mathrm{V}_{\mathrm{p}}\right)$; and $) ; \mathrm{R}_{0} \mid \mathrm{v}_{\mathrm{e}}, \mathrm{V}_{\mathrm{e}} \sim \mathrm{W}^{-1}\left(\mathrm{v}_{\mathrm{e}}\right.$, $\mathrm{V}_{\mathrm{e}}$ ) with hyperparameters $\mathrm{V}_{\mathrm{a}}=\widehat{\mathrm{G}}_{0}, \mathrm{~V}_{\mathrm{P}=\widehat{\mathrm{P}}_{0}}$, and $\mathrm{V}_{\mathrm{e}}$ $=\widehat{R}_{0}$, and the degrees of freedom $\mathrm{v}_{\mathrm{a}}=\mathrm{v}_{\mathrm{p}}=\mathrm{v}_{\mathrm{e}}=2$, chosen to provide flat priors.

The (co)variance components were estimated (posterior means) using the Gibbs Sampler algorithm, available in the GIBBS3F90 software (Misztal et al. 2002). A total of 250,000 samples were generated, assuming a burn-in period of 50,000 and a thin interval of 5 iterations. Thus, 40,000 samples were used to determine the posterior distributions of parameters. Lower and upper bounds of the highest $95 \%$ posterior probability density regions were obtained for each trait. Convergence criteria were based on graphical analysis, Geweke (1992) and Raftery and Lewis (1992) test, using the "Bayesian Output Analysis" package (Smith 2007) of R software (R Development..., 2019). Genetic trends were estimated by linear regression of the breeding values as a function of generation using Statistical Analysis System ${ }^{\circledR}$ software (Statistical..., 2008) and the coefficients were considered significant when $\mathrm{p}$-value $<0.01$.

\section{RESULTS}

The descriptive statistics for the analyzed reproductive traits are presented in Table 1.

The magnitudes of the genetic, permanent environmental, and residual (co)variance components (Table 2, 3 and 4 , respectively) defined the heritability and genetic correlation (Table 5) estimates for evaluated reproductive traits in Wistar rats.

Table 1. Descriptive statistics of reproductive traits in Wistar rats

\begin{tabular}{lllll}
\hline Traits $^{1}$ & $\mathrm{~N}$ & $\mathrm{M}(\mathrm{SD})$ & $\mathrm{MIN}$ & MAX \\
\hline LS (pups) & 1162 & $10.12(3.56)$ & 1.00 & 18.00 \\
CI (days) & 949 & $27.07(6.57)$ & 19.00 & 75.00 \\
PM (\% pup) & 1167 & $6.57(17.70)$ & 0.00 & 100.00 \\
CAN (\% pup) & 1167 & $3.67(11.64)$ & 0.00 & 100.00 \\
\hline
\end{tabular}

${ }^{1} \mathrm{LS}=$ litter size at birth; $\mathrm{CI}=$ calving interval; $\mathrm{PM}=$ pup mortality; CAN = maternal cannibalism; $\mathrm{N}=$ number of observations; $\mathrm{M}(\mathrm{SD})=$ mean ( standard deviation); $\mathrm{MIN}=$ minimum value; $\mathrm{MAX}=$ maximum value. 
Table 2. Posterior mean estimates, standard deviation and $95 \%$ highest posterior density interval of the genetic variance (on the diagonal) and covariance (below diagonal) components in Wistar rats

\begin{tabular}{lllll} 
Traits $^{1}$ & LS & CI & PM & CAN \\
\hline \multirow{2}{*}{ LS } & $1.22(0.82)$ & - & - & - \\
& {$[0.01 ; 2.79]$} & & & - \\
CI & $0.91(5.62)$ & $102.10(112.62)$ & - & - \\
& {$[-10.42 ; 11.46]$} & {$[0.27 ; 325.10]$} & & \\
PM & $-4.91(3.73)$ & $-2.04(5.13)$ & $44.22(19.68)$ & $11.01(5.29)$ \\
& {$[-12.60 ; 1.86]$} & {$[-12.16 ; 8.32]$} & {$[9.61 ; 82.54]$} & {$[2.19 ; 21.11]$} \\
CAN & $849.20(593.07)$ & $2.39(23.83)$ & $16.64(7.60)$ & {$[1.81 ; 31.58]$} \\
& {$[-162.40 ; 2009.0]$} & {$[-47.66 ; 49.55]$} & & \\
\hline
\end{tabular}

${ }^{1} \mathrm{LS}=$ litter size at birth; $\mathrm{CI}=$ calving interval; $\mathrm{PM}=$ pup mortality; CAN = maternal cannibalism.

Table 3. Posterior mean estimates, standard deviation and $95 \%$ highest posterior density interval of the permanent environmental variance (on the diagonal) and covariance (below diagonal) components in Wistar rats

\begin{tabular}{lllll}
\hline Traits $^{1}$ & LS & CI & PM & CAN \\
\hline \multirow{2}{*}{ LS } & $1.50(0.64)$ & - & - & - \\
& {$[0.27 ; 2.71]$} & & & - \\
CI & $-0.24(3.01)$ & $110.30(110.95)$ & - & - \\
& {$[-5.95 ; 5.58]$} & {$[0.29 ; 328.20]$} & & \\
PM & $-2.28(2.62)$ & $1.52(4.28)$ & $23.32(12.97)$ & $10.43(4.53)$ \\
& {$[-7.29 ; 2.85]$} & {$[-7.21 ; 9.34]$} & {$[1.29 ; 46.93]$} & {$[2.22 ; 19.31]$} \\
CAN & $38.90(19.39)$ & $2.81(23.71)$ & $-2.92(5.54)$ & {$[-13.02 ; 8.76]$} \\
\hline
\end{tabular}

${ }^{1} \mathrm{LS}=$ litter size at birth; $\mathrm{CI}=$ calving interval; $\mathrm{PM}=$ pup mortality; CAN = maternal cannibalism.

Table 4. Posterior mean estimates, standard deviation and 95\% highest posterior density interval of the residual variance (on the diagonal) and covariance (below diagonal) components in Wistar rats

\begin{tabular}{lllll} 
Traits $^{1}$ & LS & CI & PM & CAN \\
\hline LS & $9.17(0.42)$ & - & - & - \\
& {$[8.33 ; 10.00]$} & & & - \\
CI & $-2.80(1.33)$ & $44687.90(3546.60)$ & - & \\
& {$[-5.39 ;-0.14]$} & {$[37600.00 ; 51400.00]$} & & - \\
PM & $-9.46(1.69)$ & $5.83(3.19)$ & $271.35(13.21)$ & \\
& {$[-12.81 ;-6.19]$} & {$[-0.50 ; 12.07]$} & {$[245.60 ; 297.00]$} & $124.19(6.28)$ \\
CAN & $563.80(42.29)$ & $6.87(111.57)$ & $-1.25(5.84)$ & {$[111.90 ; 136.50]$} \\
& {$[480.30 ; 645.50]$} & {$[-205.20 ; 231.30]$} & {$[-12.75 ; 10.22]$} & \\
\hline
\end{tabular}

${ }^{1} \mathrm{LS}=$ litter size at birth; $\mathrm{CI}=$ calving interval; $\mathrm{PM}=$ pup mortality; CAN = maternal cannibalism.

Heritability estimates for the evaluated reproductive traits presented low magnitude (Table 5). The highest heritability was observed for LS and PM, 0.10 and 0.13 , respectively, for CAN the heritability was 0.07 , while an estimate close to zero for CI was obtained, 0.012. A strong and positive genetic association was observed between CAN and LS, and CAN and PM, 0.77 and 0.78 (Table 5), respectively. For the other traits, the genetic correlations were not significant (95\% highest posterior density interval containing zero) and thus, they were not included in the discussion section.

Genetic trend was positive for LS (Figure 1) and negative for PM and CAN (Figure 2 and 3, respectively). 
Table 5. Posterior mean estimates, standard deviation and $95 \%$ highest posterior density interval of the heritability (on the diagonal) and genetic correlation (above diagonal) in Wistar rats

\begin{tabular}{lllll}
\hline Traits $^{1}$ & LS & CI & PM & CAN \\
\hline LS & $0.10(0.06)$ & $0.11(0.66)$ & $-0.62(0.37)$ & $0.77(0.59)$ \\
& {$[0.01 ; 0.22]$} & {$[-0.97 ; 0.99]$} & {$[-0.99 ; 0.12]$} & {$[0.68 ; 0.99]$} \\
CI & - & $0.01(0.03)$ & $-0.31(0.60)$ & $0.06(0.70)$ \\
& & {$[0.00 ; 0.10]$} & {$[-0.99 ; 0.77]$} & {$[-0.97 ; 0.99]$} \\
PM & - & - & $0.13(0.05)$ & $0.78(0.23)$ \\
& & & {$[0.02 ; 0.24]$} & {$[0.29 ; 0.99]$} \\
CAN & - & - & - & $0.07(0.06)$ \\
& & & & {$[0.00 ; 0.18]$} \\
\hline
\end{tabular}

${ }^{1} \mathrm{LS}=$ litter size at birth; $\mathrm{CI}=$ calving interval; $\mathrm{PM}=$ pup mortality; $\mathrm{CAN}=$ maternal cannibalism.

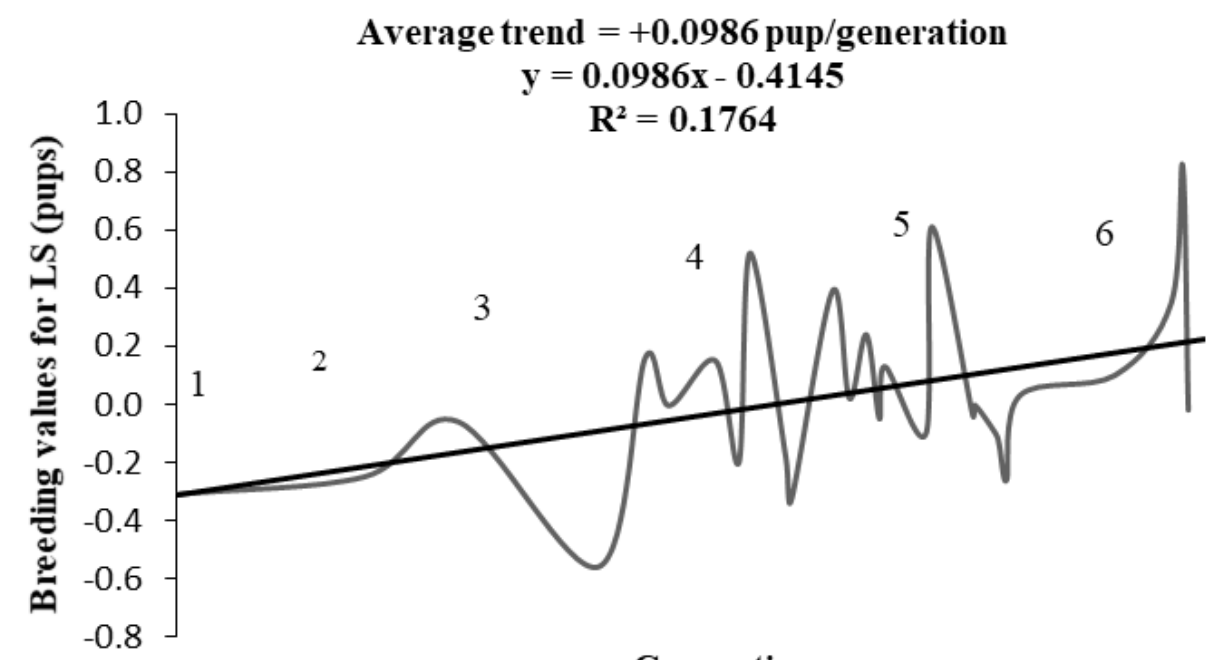

\section{Generations}

Figure 1. Genetic trend estimates for litter size at birth (LS) over 6 generations of Wistar rats.

Average trend $=-\mathbf{1 . 0 0 8 5} \mathrm{pup} / \mathrm{gener}$ ation

$y=-1.0085 x+4.1529$

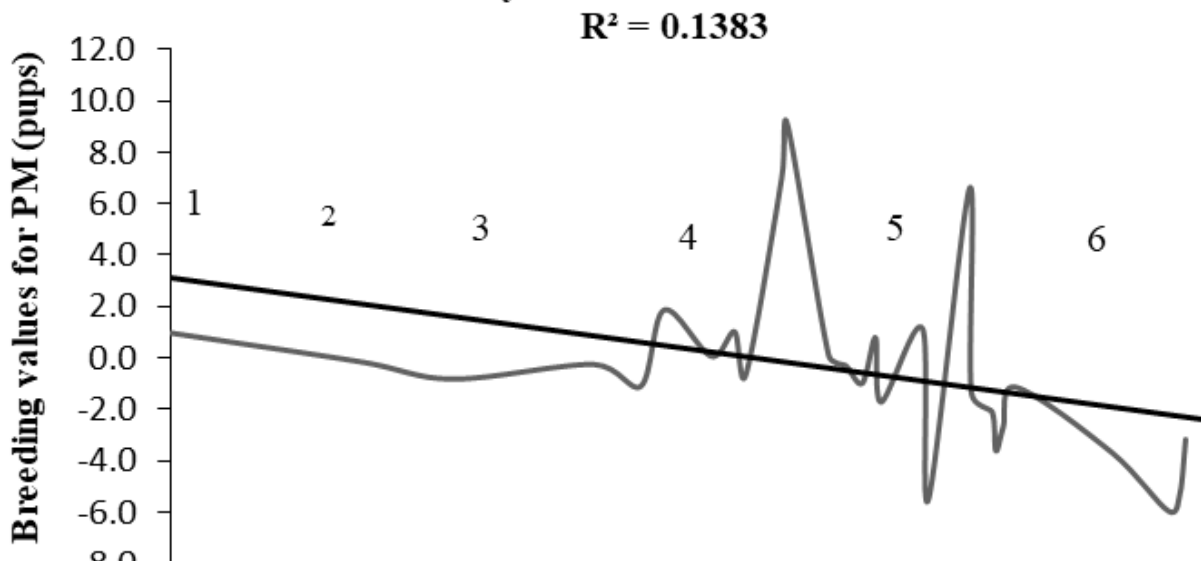

Generations

Figure 2. Genetic trend estimates for pup mortality (PM) over 6 generations of Wistar rats. 


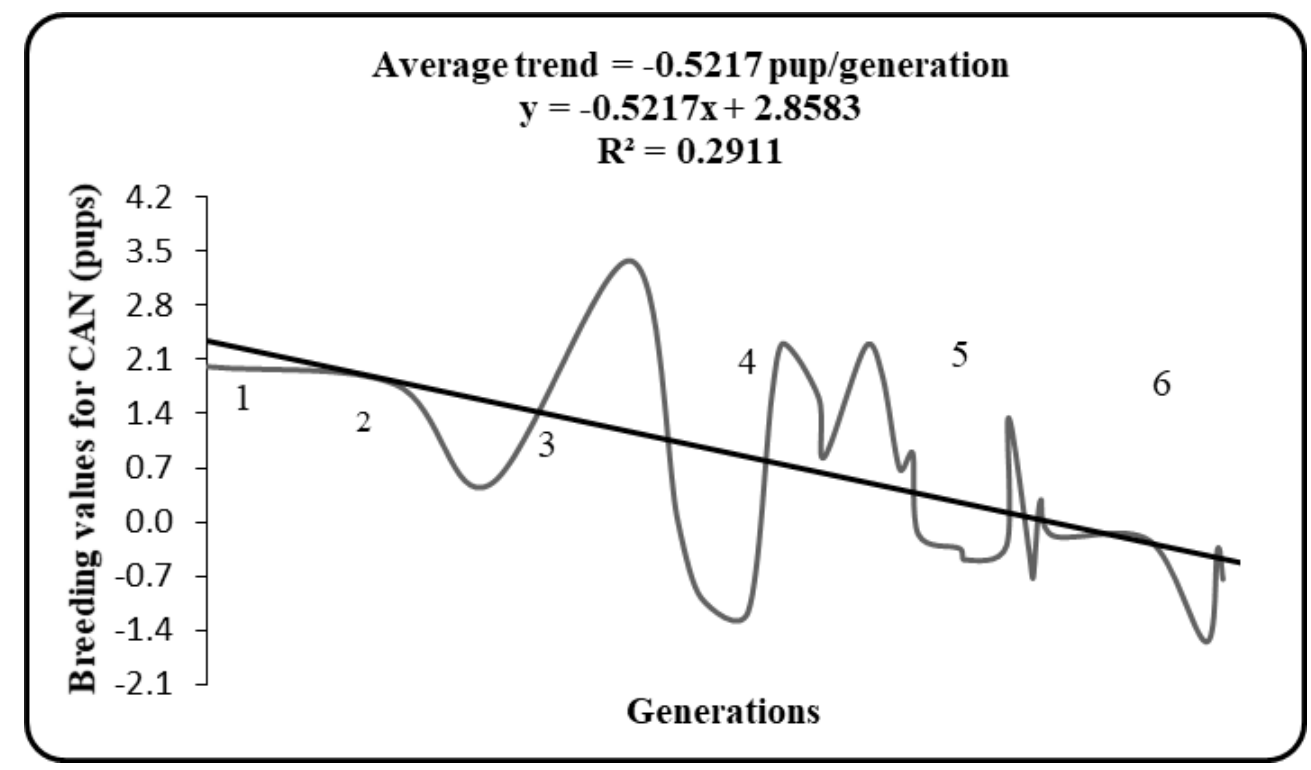

Figure 3. Genetic trend estimates for maternal cannibalism (CAN) over 6 generations of Wistar rats.

The regression coefficient was not significant for $\mathrm{CI}(\mathrm{P}=0.6560)$, indicating that the breeding values of animals for this trait did not change over generations. The regression coefficient for LS was significant $(\mathrm{P}<0.0001)$ and there was an increase of 0.09027 birth pups by generation (Figure 1). A significant regression coefficient $(\mathrm{P}=0.0040)$ was obtained for PM and there was a decrease of 1.0085 pups by generation (Figure 2). For CAN, the regression coefficient was also significant $(\mathrm{P}<0.0001)$ and there was a decrease of -0.5217 pups by generation (Figure 3 ).

\section{DISCUSSION}

Although the heritability estimates for the evaluated reproductive traits presented low magnitude it is still possible to reach genetic gain since there is additive genetic variability (Gianola and Rosa, 2015). These findings suggest that these traits can be used as selection criteria in breeding programs of this Wistar rat population. The genetic progress of these traits may be accelerated through increasing selection intensity, in order to reduce dam numbers, although this should be limited by the required replacement rate. It is important to emphasize that the number of selected dams should be observed, since increasing selection pressure could reduce genetic variability and cause inbreeding depression (Schefers and Weigel, 2012). Previous studies with mice, Vangen (1993) and Holt et al. (2005) observed that litter size at birth presented lower heritability on the selected population than unselected, suggesting reduced genetic variability due to selection intensification. Formoso-Rafferty et al. (2016) considering the litter size and survivability at weaning, noticed that the low environmental variability mice line for the birth weight was preferred from a welfare point of view, but its superiority from the productivity was not clear.

As shown the studied reproductive traits seem to be mostly influenced by non-additive genetic and environmental effects, suggesting that in addition to animal selection the environment should also be controlled throughout the Wistar rat production process. According to Weaver et al. (2015), physical and environmental factors such as noise, lighting, routine cleaning and the separation of a dam from her pups may influence rodent maternal behavior in a laboratory and, consequently, affect the dam welfare and reproductive performance. Thus, these factors can have negative effects on the animals and influence the evaluated traits, although a strict control of some of these environmental sources was done along the experimental period. The dam selection for the traits assessed in the present study would allow for a better birth and mortality control, reducing feeding and management costs. In addition, this would ensure regular availability of the animals according to the researcher's monthly or annual demands, allowing better production planning. 
On the other hand, the genetic correlation $\left(r_{g} 0.77\right)$ between LS and CAN suggests that selection for increasing litter size may lead to higher maternal cannibalism incidence in the evaluated Wistar rat population. Aggressive dam behavior towards offspring may be related to both factors, since CAN is an inheritable trait according to the genetic variability found $\left(h^{2}=0.07\right)$, as reported by Perrigo et al. (1993) and Poikonen et al. (2008), in addition to environmental factors (Korpela et al., 2010, Weber et al., 2013, Tarôco et al., 2015). Korpela et al. (2010) reported that increasing density populations can result in higher infanticide rates in a vole's population. The resource competition hypothesis is usually discussed, also to reduce competition against her own female offspring and increase her relative genetic contribution to the next generation (Korpela et al., 2010). Although selecting for LS increases CAN in the present study, the genetic trends for these traits showed increasing breeding values for LS and decreasing for CAN over the six generations. Therefore, we believe that these traits may have undergone direct or indirect selection, suggesting that antagonistic traits can act together to fix both within the population.

The genetic correlation (rg 0.78) between PM and CAN suggests that the selection for the reduction of one would result in decreasing the other. According to Weber et al. (2013), pup mortality is a considerable problem in laboratory animal breeding, since the survival of the pups is related to maternal ability and her reaction to environmental disturbances. Weaver et al. (2015) reported that rodent dams may go through a stress period during postpartum related to serotonin levels and its inhibition may be responsible for regulating mood disorders and well-being. The pups are dependent on their mother for nutrients and thermoregulation during life early days. The maternal stress can compromise offspring care causing higher mortality rates than expected in the breeding laboratory mouse (Weber et al., 2013). As shown by genetic trends, we believe that the evaluated dams in this study may have improved environmental and nutritional conditions over generations. Thus, increasing well-being and decreasing the breeding values for CAN and PM. We suggest these results can be directly related to the selected dams which did not present these behaviors during their productive life, leading to increased numbers of weaned animals per litter.
Monitoring genetic trends for these reproductive traits is important to evaluate the efficiency of direct or indirect selection mechanisms applied to this Wistar rat population. In addition, it can indicate the need for changes in selection criteria and intensities according to the needs of the production system. Although the record number used was restricted, this study helped to understand the genetic architecture of reproductive traits in this Wistar rat population. We suggest performing further studies in order to explore these phenotypes with the highest record number.

\section{ACKNOWLEDGEMENTS}

The authors acknowledge CAPES, CNPq and FAPEMIG.

\section{REFERENCES}

ARENDS, D.; HESSE, D.; BROCKMANN, G.A. Invited review: genetic and genomic mouse models for livestock research. Arch. Anim. Breed., v.61, p.87-98, 2018.

FERNÁNDEZ, J.; MORENO, A.; GUTIÉREEZ, J.P. et al. Direct and correlated selection response for litter size and litter weight at birth in the first parity in mice. Livest. Prod. Sci., v.53, p.217-223, 1998.

FORMOSO-RAFFERTY, N.; CERVANTES, I.; IBÁÑEZ-ESCRICHE， N.; GUTIÉRREZ, J.P. Correlated genetic trends for production and welfare traits in a mouse population divergently selected for birth weight environmental variability. Animal, v.10, p.1770-1777, 2016.

GEWEKE, J. Evaluating the accuracy of sampling-based approaches to the calculation of posterior moments. In: BERNARDO J.M.; BERGER J.; DAWID A.P.; SMITH A.F.M. (Eds.). Bayesian statistics. Oxford: Oxford University Press, 1992. p.69-193.

GIANOLA, D.; ROSA, G.J.M. One hundred years of statistical developments in animal breeding. Ann. Rev. Anim. Biosci., v.3, p.19-56, 2015. 
HOLT, M.; MEUWISSEN, T.; VANGEN, O. Long-term responses, changes in genetic variances and inbreeding depression from 122 generations of selection on increased litter size in mice. J. Anim. Breed. Genet., v.122, p.199-209, 2005.

KORPELA, K.; SUNDELL, J.; YLÖNEN, H. Density dependence of infanticide and recognition of pup sex in male bank voles. Behaviour, v.147, p.871-881, 2010.

LUKAČ, D.; VIDOVIĆ, V.; VASILJEVIĆ, T.; STANKOVIĆ, O. Estimation of genetic parameter and breeding values for litter size in the first three parity of landrace sows. Biotechnol. Anim. Husbandry, v.32, p.261-269, 2016.

MATTARAIA, V.G.M.; MOURA, A.S.A.M.T. Produtividade de ratos Wistar em diferentes sistemas de acasalamento. Ciênc. Rural, v.42, p.1490-1496, 2012.

MISZTAL, I.; TSURUTA, S.; STRABEL, T. et al. BLUPF90 and related programs (BGF90). In: WORLD CONGRESS ON GENETICS APPLIED TO LIVESTOCK PRODUCTION, 7., 2002, Montpellier. Proceedings... Montpellier, France: [s.n.], 2002. (Communication 28-07).

PERIPATO, A.C.; BRITO, R.A.; MATIOLI, S.R. et al. Epistasis affecting litter size in mice. J. Evol. Biol., v.17, p.593-602, 2004.

PERRIGO, G.; BELVIN, L.; QUINDRY, P. et al. Genetic mediation of infanticide and parental behaviour in male and female domestic and wild stock house mice. Behav. Genet., v.23, p.525-531, 1993.

POIKONEN, T.; KOSKELA, E.; MAPPES, T.; MILLS, S.C. Infanticide in the evolution of reproductive syncrony: effects on reproductive success. Evolution, v.62, p.612-621, 2008.
R DEVELOPMENT core team: a language and environment for statistical computing. Vienna: R Foundation for Statistical Computing, 2019. Available in: <http://www.R- project.org>. Accessed in: 20-12-19.

RAFTERY, A.E.; LEWIS, S.M. One long run with diagnostics: implementation strategies for Markov chain Monte Carlo. Stat. Sci., v.7, p.493-497, 1992.

ROUT, P.K.; MATIKA, O.; KAUSHIK, R. et al. Estimation of genetic parameters and genetic trends for milk yield traits in Jamunapari goats in semiarid tropics. Small Ruminant Res., v.153, p.62-65, 2017.

SCHEFERS, J.M.; WEIGEL, K.A. Genomic selection in dairy cattle: integration of DNA testing into breeding programs. Anim. Front., v.2, p.4-9, 2012.

SMITH, B.J. Boa: an R package for MCMC output convergence assessment and posterior inference. J. Stat. Software, v.21, p.1-37, 2007.

STATISTICAL analysis systems user's guide. Version 9.2. Cary: SAS Institute Inc., 2008.

TARÔCO, G.; GAYA, L.G.; RESENDE, D. R. et al. Environmental and dam effects on cannibalism in Wistar rat litters. Acta Sci. Biol. Sci., v.37, p.225-229, 2015.

VANGEN, O. Results from 40 generations of divergent selection for litter size in mice. Livest. Prod. Sci., v.37, p.197-211, 1993.

WEAVER, S.R.; CRONICK, C.M.; PRICHARD, A.P. et al. Use of the RatLoft decreases pup mortality in lactating mice. Lab. Anim., v.50, p.370-378, 2015.

WEBER, E.M.; ALGERS, B.; WÜRBEL, H. et $a l$. Influence of strain and parity on the risk of litter loss in laboratory mice. Reprod. Domest. Anim., p.1-5, 2013. 